\title{
Climbing Walls to feel at Home: Palestinian Climbers re- appropriating Space
}

\section{Olga BLÁZQUEZ SÁNCHEZ}

PhD candidate at Departamento de Estudios Árabes e Islámicos y Estudios Orientales. Universidad Autónoma de Madrid (UAM) ${ }^{1}$.

olga.blazquez@uam.es

Recibido 23/2/2017. Revisado y aprobado para publicación 07/06/2017.

Para citar este artículo: Olga Blázquez Sánchez (2017) , “Climbing Walls to feel at Home: Palestinian Climbers reappropriating Space" en Revista de estudios internacionales mediterráneos,22, 129-140.

Para acceder a este artículo: https://doi.org/10.15366/reim2017.22.006

\begin{abstract}
Rock climbing is an outdoor activity that has recently become popular in Palestine partly due to the development of the Wadi Climbing project. A climbing community of local climbers has therefore developed and this implies new relationships and belonging ties between space and Palestinians are appearing. This article explores the ability of climbers to re-appropriate a space such as the natural landscape of the West Bank that has been under Israeli occupation since 1967.
\end{abstract}

Key words: Palestine, West Bank, climbing, Wadi Climbing, re-appropriation of space.

\section{Resumen}

La escalada es una actividad que se realiza al aire libre y que se ha popularizado recientemente en Palestina gracias, en parte, a la puesta en marcha del proyecto Wadi Climbing. Ello ha dado lugar a la aparición de una comunidad local de escaladores/as, lo que supone el desarrollo de nuevas relaciones y lazos de pertenencia entre la población palestina y el entorno. Este artículo explora la capacidad de dichos escaladores/as palestinos/as para reapropiarse de un espacio como el paisaje natural de Cisjordania, que vive bajo la ocupación israelí desde 1967.

Palabras clave: Palestina, Cisjordania, escalada, Wadi Climbing, reapropiación del espacio.

\footnotetext{
${ }^{1}$ This research has been possible thanks to a PhD grant programme (FPI-UAM).
} 
"On sait, en effet, que dans des conditions émotionnelles données

la présence de l'obstacle accentue la tendance au mouvement."

Frantz Fanon ${ }^{2}$

"It is a known fact that under certain emotional circumstances an obstacle actually escalates action."

Richard Philcox, trans. ${ }^{3}$

\section{Introduction}

The objective of this article is to provide a reflection on the role of civil society in the process of building spaces of pleasure within conflict contexts, such as Palestine. The research has been developed by looking at one specific case study, which is being described and analyzed with the aim of developing an academic reflection and building theory in close relation to the facts and to many personal experiences. Achieving aseptic neutrality and objectivity is not the core intention in developing this research. In fact, the focus is not on providing something scientific, but on writing a polyhedral narrative gathering different voices and points of view regarding spatiality in Palestine and the role played by civil society in modifying the way space is conceived and experienced.

The case study here addressed is the Wadi Climbing project, a company funded by two American climbers in Ramallah in 2014 that allowed for the development of a climbing community in Palestine. The community, and not the Wadi Climbing project itself, is what is being studied. However, it is nowadays impossible to clearly distinguish between Wadi Climbing and the climbing community, since most Palestinian climbers are trained by the Wadi Climbing instructors and practice their climbing skills in the Wadi Climbing boulder gym. Therefore, no real distinction is being made between Wadi Climbing and the Palestinian climbing community. Both are actors that interact with each other and develop concurrently. Indeed, both actors are interdependent since none of them can exist without the other. They are supporting each other's existence. This makes things become really complex. But, instead of trying to clarify complexity, I try to articulate the different components that take part in this complexity in order to achieve a story full of different and diverse subjectivities, including mine as a climber.

Through these pages, the Palestinian climbing community is conceived as being part of the Palestinian civil society and this could be problematic from the point of view of some authors. The difficult question to answer is how a concept such as civil society, traditionally developed in the field of political science, can fit in this research. First of all, it has to be mentioned that civil society is not a concept but a debate. Many different definitions have been developed by authors such as Hegel, Tocqueville, Marx, Gramsci and Habermas (and more) and there is still no consensus on its meaning. This research is not an attempt to provide a new definition, but an attempt to make the debate even more problematic. Civil society is addressed in this article in a very broad and interrelational sense. Civil society is what happens (not only what merely is) in the undefined space of the in-betweenness. Many authors have already placed civil society in-between the State / market and individuals (society). Some of them have also argued that independence is indispensable for civil society to be recognizable. So, theoretically, civil society cannot take part in

2 Fanon, Frantz. 2002. Les damnés de la terre. Paris: La Découverte/Poche.

3 Philcox, Richard, trans. 2004. The wretched of the earth. New York: Grove Press 
the State nor in the market, However, the question is: can independence somehow be fully achieved? There might be no answer to this question. Independence may be an illusion the existence of which mostly occurs in theory. Civil society then is what happens in-between the State, the market and individuals (and other social agents such as families, etc). But, then, I would argue that, instead of being totally independent, civil society is inevitably interrelated to them. This problematic point of view regarding the debate does not imply that civil society has no agency. Indeed its agency comes from its ability to have influence on others because it is related to them. Civil society is not the State nor the market, but it is interrelated to both of them. A climbing community that defines itself as such, and is, therefore, fully conscious of its own existence as a defined collective within society and its role (providing themselves and others with a recreational and pleasant activity in a conflict context) can be included as being part of civil society. The main reason why it has been decided to conciously include the Palestinian climbing community as part of the Palestinian civil society is because, even though my main objective in this research is to gather different voices, perspectives and experiences regarding what an activity such as climbing produces in an occupied environment such as the West Bank, it is also my objective (although it is not here developed) to enlarge the definition of civil society to include as many social actors as possible. This way, it will become possible to actually understand the role of organizations such as Wadi Climbing.

The methodology developed during the research process included personal interaction with different actors (Palestinian and international climbers, Palestinian activists and members of the Wadi Climbing project were interviewed via email) as well as consulting different sources of information such as news on the media, social networks, academic literature and maps. The interviews were necessary in order to collect different personal perspectives and experiences about climbing in Palestine. One of the co-founders of the Wadi Climbing project, as well as two Palestinian climbers, two international climbers, a Palestinian activist and the founder of an adventure trips company in Jordan were interviewed. Some of the interviews took place via email so that every interviewee had enough time, intimacy and freedom to answer the questions in his/her own way, others just took place as conversations through Facebook Messenger. In the interviews, all the questions were open, so that respondents could choose what to share and it was not mandatory to answer all of them. It was a methodological decision not to necessarily interview a great number of people since it was not the objective of this research to make statistics nor to analyse discourse trends, but to gather some different perspectives about the research topic. Each interviewee was, therefore, a valuable source of information and their experiences were individually taken into account. The discourses of the interviewees and their points of view were considered to be as important as information and data provided by scholars. I called this way of interviewing, which is widely open, personal interaction because it did not merely consist of a list of questions to be answered for the sake of academic knowledge. What actually took place was a dialogue. However, of course, there were questions. That is why I provide a list of questions that I asked to the different interviewees. Questions asked to Tim Bruns, co-founder of Wadi Climbing, were a) how has rock climbing contributed to the building of new social communities?; b) how do you feel rock climbing is perceived by new climbers (or even people that do not climb at all) in Ramallah?; and c) do you think rock climbing provides a new way of looking at space (landscape)? Questions asked to Palestinian rock climbers included a) how long have you been climbing?; b) why did you decided to start climbing?; c) has climbing produced a change in yourself?; d) have you ever thought about your relationship with space or landscape 
when you climb and if so, could you describe it?; and e) what does climbing mean to you now? Finally, questions asked to international rock climbers were a) what do you think it means to climb in Palestine?; b) based on your own experience as a climber and the things you feel when climbing, do you think there is a change in the way space is perceived and what do you think it implies in Palestine?; and c) what is your point of view regarding the Wadi Climbing project?

In addition to the interviews, some news related to the topic appearing on the media and also the Wadi Climbing Facebook account were analyzed. This helped enormously to understand how the climbing community in Palestine is becoming visible and also to study the way social interaction is being developed as a consequence of one simple activity: climbing. Finally, some ideas of authors that have reflected on the role of spatiality in Palestine such as Eyal Weizman or Léopold Lambert as well as some authors' reflections on the role of climbing and mountaineering in redefining space (Éric Léséleuc, Amilhat Szary) are being addressed.

Besides the academic objective, this article is also an attempt to do research in a different way. As already said, objectivity and neutrality are not the main goals here. Instead, it is agreed that, as Donna Haraway argued in Simians, cyborgs, and women: the reinvention of nature (1991), knowledge is never objective. Only situated knowledges can happen, which means that every academic or scientific research comes ideologically from somewhere and is intimately linked to a given perspective. Becoming conscious of the position from which I am doing research is therefore necessary to fully understand this article ${ }^{4}$. Producing knowledge always implies a question of ethics. Epistemology is inherently a colonial artifact. Epistemicides, as Boaventura de Sousa Santos (2010) and Ramón Grosfoguel (2013) have already proved, are an intrinsic part of History. Therefore, certain knowledges have traditionally been conceived as being at the centre of the epistemological apparatus whereas others (local, indigenous, non-scientific knowledges) are located just in the periphery. This article has also been written with the aim of producing knowledge from other spaces. The kind of knowledge produced by Palestinian climbers is as valid as knowledge produced by the quoted authors. All their voices mix together in these pages. This decolonial perspective applied to the act of producing knowledge is also methodologically developed through my attempt of avoiding epistemological violent extractivism. As already said, the interviews that I conducted via email happened in a non-academic way and I tried not to treat the different interviewees just as sources from where to extract knowledge, but as people that decided to share their points of view with $\mathrm{me}^{5}$.

\section{Space in Palestine}

Understanding how space is organized in Palestine is key to understand the Israeli-Palestinian conflict. Architectural structures always have an influence on people since they impose a specific way of moving through space. Bernard Tschumi, in Architecture and Disjunction (1996) argued that

\footnotetext{
${ }^{4}$ It is also necessary for the reader to identify the gaps that I may not be able to cover because of my point of view, my position and my context. That is why I will try to do a list with some of the categories that define who and where I am (now): PhD student, Spanish, white, young, genderqueer, feminist, climber, ecologist, actress. Describing my identity does not imply that I wrote this article from a perspective that includes all the concepts that I have used to describe myself. It means that the different parts of myself may have had an influence on what I wrote and I do not want to hide it. I also have to say that I have not had the opportunity to spend some time in Palestine yet due to a trimalleolar ankle fracture that stopped me from travelling to Ramallah in December 2016, which means this article lacks information coming from in situ observation and field research. As a consequence, these lines can be read as a preliminary research that could be further developed in the future.

${ }^{5}$ Finally, I would like to mention that, even though I am writing these lines, this article has been possible not only because of me, but also because of a researching process in which I got feedback from the 2016 APSA-MENA workshop organizers and fellows, the people I interviewed during my research, my PhD supervisor and other colleagues. Again, I would like to highlight that all their (our) voices are here mixed.
} 
"society produces space but it also becomes a prisoner of space." (23). The space designed by society imposes a certain choreography of movements. Sometimes, these choreographies defined by architecture can be multiple, which means, many different ways of moving are possible. But, architecture can also be very constrictive. That is what happens in Palestine. The Israeli occupation implies an architectural strategy that has been well described by Eyal Weizman in Hollow land: Israel's architecture of occupation (2012). This strategy is based on a process of territorial fragmentation, the building of Israeli settlements in the Palestinian territories, the development of structures for surveillance and control (checkpoints) and the creation of apartheid infrastructures such as the Israeli-only roads across the West Bank. A process of gentrification in some of the ancient cities of Palestine, such as Jaffa, has also been well documented. Jaffa has been absorbed by the Israeli city of Tel Aviv and has become one of its neighbourghoods since 1950, which was followed by a process of "Israelization" of space. Locals were therefore displaced from Jaffa and the abandoned Palestinian buildings were demolished or remodeled. Finally, these buildings started being inhabited by Israelis. This process of gentrification and displacement of Palestinian population has also been sheltered by the Absentees' Property Law (1950), a legal tool for the confiscation and annexation of Palestinian lands based on the concept of "absence". Lizzie Dearden in her article for the Independent, "Israel can now legally seize Palestinian homes in Jerusalem under 'absentees' property law" (April 17, 2015), provides a clear and brief definition of what an absentee consists of. It is defined as "anyone who lives in a nation designated hostile, including Lebanon, Egypt, Syria, Saudi Arabia and Jordan, or in an area of Israel outside state control". This includes pre-1948 Palestinians living in territories that happened to fall under the Israeli rule who were forced to leave their homes. However, a Palestinian can also become an absentee without even moving from his/her own home due to the changeable boundaries of Israel during its history as an state. This law is still being applied today.

The displacement of Palestinians is also part of a broader strategy of ethnic cleansing, described by Ilan Pappe in The Ethnic Cleansing of Palestine (2007), and a process of memoricide consisting of erasing Arabic place names and replacing them by Hebrew ones. The memoricide has also taken the shape of an ecologization process. The Jewish National Fund has approved different natural areas to be built over the ruins of Palestinian villages (Pappé, 2007: 302-308) for the sake of the environment. This process is called by some activists greenwashing and allows for the normalization of the Israeli occupation. Besides this, the uprooting of Palestinians from their homeland was also based on an israelization of the physical space itself. An example is the replacement of certain autochthonous flora species (olive trees, almond trees, fig trees...) by European trees such as pines (Ramos Tolosa, 2015: 171). All these spatial occupation strategies developed by Israel cause Palestinians' land dispossession, which means it is increasingly difficult for Palestinians to access space or landscape as they used to do it in the past.

Finally, in addition to the Israeli occupation, which is a crucial factor that must necessarily be taken into account in order to understand the way space is designed in Palestine, there are other factors that contribute to the spatial conflict, such as the interest of real estate companies to develop their projects in Palestine, the increase of business activity related to urban development and speculation, etc. The Rawabi project, for instance, has created tension with surrounding landowners who argue that most of the land used for the project has been taken "against their will and with minimal compensation", Ben Hattem explains in his article for the Middle East Eye, "Palestine's first planned city causes tensions" (February 12, 2015). Rawabi is the first planned city 
built in the West Bank. It is located $9 \mathrm{~km}$ north of Ramallah and its municipal area is 6, 300, 000 square meters. The city is supposed to be home to around 25,000 residents (initially), a number that is expected to increase up to a maximum of 40,000 people afterwards. The project depends on an investment of more than 1 billion USD and it has been developed by the Qatari-Palestinian Bayti Real Estate Investment Company since January 2010 (Rawabi, 2016). The city will be affordable only for middle class families, since "apartment prices in Rawabi run from $\$ 65,000$ $\$ 180,000 "$ (Hattem, 2015), which again can be considered as a case of gentrification. Local landowners will lose their access to the land and the working class will not be able to buy a house there because of the prices.

In this context characterized by land dispossession, spatial access difficulties and constrictions of movement, the re-definition of movement itself can produce a change. Omar Khan and Dorita Hannah in "Performance/Architecture. An interview with Bernard Tschumi" (2008) explained that "architecture is about activating space through the movement of bodies" (53). This means, subversive or unexpected ways of moving through a given territory can activate space differently, in a non-normative way. And it can also produce a new way of engaging to landscape. So, what would developing climbing activities in Palestine imply? This is one of the main questions of this research.

\section{Climbing in Palestine}

Before climbing experienced its extraordinary increase in Palestine, there were already projects that focused on the relationship between movement, outdoor activities and space in the Palestinian context. Tony Howard and Di Tylor, two experienced rock climbers, mountaineers and explorers, developed what they called the Nativity Trail, "a 10 day, $160 \mathrm{~km}$ walk symbolising the journey of Mary \& Joseph from Nazareth to Bethlehem." (Nomadstravel, 2016). The objective of this project was both to contribute to the peacebuilding process in Palestine and to provide a tool for walkers to discover the country. The result was a book entitled Walks in Palestine and the Nativity Trail, published in 2001 (Cicerone Press). Also the Abraham Path has been created. It is "the first long-distance walking trail across the Middle East" (Walking Palestine, 2016) and "is promoted and supported by a long list of local and international partners, coordinated by the Abraham Path Initiative" (ibid). The route "retraces the journey of Abraham" (Abraham Path, 2016) and plays a role similar to the way of Saint James in Spain. These two examples prove there has been an increasing interest in the relationship between moving through space in Palestine and its social implications. Moving therefore becomes an engine for social development and spatial awareness.

Wadi Climbing is the first climbing project developed in Palestine. It is a company that was founded in July 2014 by Tim Bruns and Will Harris, both being Americans and coming from Connecticut and Chicago respectively. By 2012 Bruns and Harris were studying Arabic and living in Amman (Jordan), and they used to climb outdoors in several locations of the region, also in Lebanon and Palestine, where they noticed the lack of recreational activities. That is the reason why the two co-founders decided to carry out the Wadi Climbing project. To the lack of leisure opportunities should be added the limited access to the already existing ones in Palestine, due to road closures, the Israeli settlements, the fragmentation of space, borders, etc. Indeed, as Nigel Wilson states in his article "Palestine's rock-climbing community on the rise", published in $A l$ Jazeera (October 3, 2015), "the vast majority of climbing infrastructure in the area has been developed by Israeli climbers in Area C". Area C is under Israeli civil and security control, where Palestinians are unlikely to move freely. Taking into account this situation, Bruns and Harris visited the country again and decided to do feasibility studies in the West Bank in order to know whether their project was possible or not. The result was positive so they moved to Ramallah afterwards. 
The objective of the company, nevertheless, is not only to provide locals with leisure opportunities, but also to achieve the consolidation of a Palestinian climbing community, which means working together hand in hand with Palestinian climbers. Bruns and Harris' final goal for the Wadi Climbing project (and specially for the recently built boulder gym), as described by Jonathan Brown in his article for the Middle East Eye, entitled "Climbing community scales new heights in Palestine" (June 22, 2015), is "to eventually be transferred to local management" in order the community to be "self-sustaining." Wadi Climbing also provides an opportunity to discover the climbing possibilities and potential of the occupied West Bank. This is key to understand the main goal of this research, which focuses on how Palestinian climbers collectively approach, engage and relate to space and landscape differently due to the development of climbing skills.

In order to achieve their objectives, the Wadi Climbing team organizes outdoor climbing trips and courses, they have also built the first boulder gym in Palestine (in Ramallah) in 2016, which allows for indoor climbing activities, training and also for meeting other climbers. This way, the boulder gym has become a community space. Finally, they have also equipped several routes with bolts in different locations with the cooperation of local municipalities. This last task has been specially difficult to perform since space is not always accessible for Palestinians. The Israeli occupation and the geographical fragmentation of Palestine actually limit the development of climbing activities. Tim Bruns' words, gathered in Aquila Style's article "Palestinians in the rocky West Bank try climbing for sport" (April 20, 2015), provide an example that illustrates the actual difficulties in space accessibility caused by occupation: "you have to take into account [the] kind of access and where (the Jewish) settlements are and where Israel parks are". Another example that helps to understand spatial structure and the level of spatial difficulties to access the climbing areas in Palestine is the way directions are explained in order to reach each place. The following instructions to arrive to the Ein Yabrud climbing site have been published in the Wadi Climbing website (last accessed July 27, 2016) and they show how to arrive to the final destination one has to pass by an Israeli settlement, a refugee camp, etc:

"Drive north on Ersal street from Al Manara circle. Take a slight right onto route 463 and drive 1 kilometer. Take a left on route 466 (the old Nablus road) and drive north past the Beit El Settlement on your right and the Jalazun refugee camp on your left.

You will soon reach an intersection where you take a right to follow signs to Dura El Kari'a village. Continue straight through Dura El Kari'a and along the bottom of a valley until you begin to ascend into Ein Yabrud village. Take your first right at the intersection with the auto repairs shop and drive through a residential neighborhood until you reach a dead end. At the dead end, continue on the dirt road and park where the road ends (near a Bedoin encampment). From there, make your way on foot into the valley"

Thus, another goal is to guarantee accessibility for Palestinians, so that they can get into the climbing areas. Until now, there are five outdoor locations that have been set up for rock-climbing in Palestine, all of them placed in Areas A (under the Palestinian Authority civil and security control) and B (under the Palestinian Authority civil control and the Israeli-Palestinian security control). These locations are Yabrud (near Bir Zeit), Ein Qiniya, Ein Yabrud, Ein Fara and a small area by the Dead Sea. 
The development of a project such as Wadi Climbing has already produced results. "Over the past year and a half, we have had over 1.400 sign ups on our climbing trips", the Wadi Climbing cofounder Tim Bruns said while being interviewed for this research. Moreover, a stable climbing community is actually on the rise, which now consists of a group of around thirty foreign and local climbers that go climbing regularly, meaning two or three times a week. Besides the amount of people involved in climbing activities in Palestine so far, it is also interesting to look at the climbing community diversity. People coming from urban areas in Ramallah, Palestinians of rural villages, bedouin kids and foreigners are used to climbing together. Climbing has become a social engine that promotes social engagement and also an activity that provides people with new spatial experiences.

\section{Climbing to re-appropriate space}

In his article "Rock climbing and territory: symbolic processes in the appropriation of a public space", Eric Léséleuc does an ethnographic research in order to analyze the way certain sports such as climbing are intrinsically linked to social issues, which allows for the re-definition of sport itself. This implies that some sports do not only consist of performing physical exercise or bodily activity, but also of performing social dynamics. Léséleuc looks at the way a small community of climbers appropriates a rock face in the south of France called Claret. He explains how the process of building a climbing community provides its members with a feeling of belonging both to the group and to the space. However, Léséleuc also argues that the process of community building can imply violence, since those identified as being others (outsiders not belonging to the community) are more likely to be rejected. But, what is interesting here for this current research is that an activity such as climbing allows for the birth of a community that develops a strong feeling of belonging and engages intensely to a certain space, which somehow becomes its territory. ${ }^{6}$ of course, as Léséleuc argues, this situation can produce violence and several conflicts, but it can also become a process of achieving the right to enjoy landscape in certain contexts in which violence and conflicts relating space already exist, such as Palestine. That is why, some of Léséleuc's analysis and arguments to describe and explain the process of spatial appropriation performed by a climbing community in France are going to be applied to analyse the Wadi Climbing project with the aim of understanding the role of climbing in a process of spatial appropriation within a conflict context. Of course, both cases (the Wadi Climbing project and the Claret climbing community) are different and the differences between them are taken into account in this research.

First of all, a clarification of what is meant by appropriation is necessary. Appropriation is a strong word with many political implications, especially when applied to talk about the Israeli-Palestinian spatial conflict. It is sometimes understood in a pejorative way. To appropriate something is to take it without permission. Appropriation here is not addressed with this pejorative meaning. It is seen as a constant, quotidian, collective and sometimes unconscious and invisible process of building homeness in problematic, conflictive and complex spaces. The main difference between the case study analyzed by Léséleuc and the Wadi Climbing case lies in the type of appropriation that each climbing community performs. Climbers at Claret appropriates a certain space that did not officially belonged to anyone before. Appropriation is not based on an already existing conflict relating space. For their part, Palestinian climbers do not merely appropriate, but re-appropriate a

\footnotetext{
${ }^{6}$ This is something I have also experienced after having spent five years climbing, Certain locations such as La Pedriza, in Madrid, become more than simply sites for climbing. Now, there are affective ties between me and the natural landscape because I have been touching the granite walls of its mountains too many times and I have felt the fear, the exhaustion, the pride, the satisfaction and the pleasure of climbing. It implies La Pedriza is not only a place anymore, but somehow its has also somehow become my territory.
} 
space in dispute. A space that is related to politics due to the historical dynamics of the Israeli occupation and the Israeli-Palestinian conflict.

The practice of re-appropriating space, meaning the practice of building homeness again, consists of a process through which "new relations with space are being forged" (Léséleuc, 2004: 95). Climbing provides space with a new meaning which implies looking at space from a different perspective. The Palestinian landscape stops being a space only related to occupation and an historical conflict to become a space for pleasure, too. Many meanings related to landscape actually overlap. Difficulties in accessing space brings the reality of occupation to the front page whereas the objective of climbing itself makes the community relate to space in a way that exceeds occupation. Climbing in Palestine implies the climbers' desire to look at space from many other perspectives besides occupation. Palestine then becomes polyhedral. In some way, climbing implies a movement against the monopolization of perspectives through which space is used to being analyzed in Palestine and, therefore, a process of decolonizing the point of view regarding the Palestinian landscape. This process of decolonization indeed allows for the re-appropriation of space since the development of new perspectives and spatial practices also imply the development of new ways of engagement.

Climbing does not only make it possible to approach space differently but also to build up new rules for socialization. Climbing allows for "the emergence of a communal sociality" (ibid: 96) that is community-specific. Very specific affective links are being developed between people and the climbed space, new ways of moving through space are being experienced, which also imply new ways of experiencing one's body, and intense feelings are being shared with others, such as fear. All of this makes it possible for the climbing community to get stronger. "Social cohesion organises at one and the same time relations with space, with others and with values in a triple process that defines the boundaries of what is possible" (ibid: 100-101). These relations are those that make the re-appropriation of space become achievable.

Léséleuc also argues that "the creation of these groups and their 'territory' poses the fundamental question of 'the other', who, as the object of violence, is driven back outside the borders" (97). However, in the Palestinian case, the other is violence itself. Space in an occupation context is intrinsically related to violence, which take the shape of access restrictions, physical borders, geographical fragmentation, obstructive architectural structures, etc. Thus, what the climbing community actually do in the West Bank is to try to experience pleasure when relating to space despite the already existing violence. Violence is what is rejected. Violence becomes the other. M., a Palestinian climber that has already been climbing for ten months, explained in an interview (May 2016) that what he is used to thinking while being on a rock face is that he is "free from all encumbrances and pressure". This implies climbing is experienced as a kind of oasis where to forget daily problems for a while. Paradoxically, the illusion of an oasis is experienced within the same space where violence is daily performed. However, this chosen amnesia (the oasis) does not imply a lack of agency. "Every time, every route and even every moment I climb, it is a new challenge for my mind and my body and my endurance ability", M. says. And S., another Palestinian climber with one year of experience climbing, explains that this activity definitely brings her "close to my[her] environment" (April 2016). It means climbing produces new ways of agency, new strategies for the development of the doing and new mechanisms of spatial awareness that makes it possible to deeply engage to space and, at the same time, it provides an 
opportunity for relaxation, pleasure and enjoyment. Therefore, climbing implies a process of (re)semiotization of space that challenges a normative way of perceiving, looking at and doing things within the Palestinian landscape.

As already said, space plays a crucial role in the everyday dynamics of Palestinian people. Due to the fragmentation of space caused by occupation, the construction of the separation barrier and the development of the Israeli settlements (among other reasons), the West Bank has become what Léopold Lambert, in Weaponized Architecture. The Impossibility of Innocence (2012), calls an archipelago. The Palestinian archipelago consists of many portions of space dispersed in the landscape, which translates into Palestinian people having to endure a frontier existence. Borders are always there. Contrary to what Anne-Laure Amilhat Szary sais in "Towards experimental mountaineering? Perspective on two tours of Alpine borders (Lionel Daudet / John Harlin, 201112)" (2013) when arguing that "international borders are above all legal conventions and those who formalised their current layout were little concerned with the possibility of their materialisation on the terrain", in the Palestinian case, the materialization of borders precedes their representation on maps. Cartography occurs always afterwards, once the terrain has already been defined in practice, and it can become rapidly obsolete due to the changeable dynamics of space. Climbing, then, develops a geography of touch (Amilhat Szary, 2013a) since climbers' bodies directly interact with the frontier space, with the terrain, and they somehow draft new limits: those reached by the flesh. Climbers actually inhabit the border (the rock face, the rocky wall), a "space normally perceived as a point in space" (ibid), as an immovable line or as a fixed and static surface. Climbers inhabit spaces traditionally perceived as "uninhabitable" (ibid) and they reappropriate them simply by climbing. This way, they fill the concept of ontology of the limit (ibid) with meaning born from personal practices and experiences.

\section{Conclusion}

The climbing context exceeds the rocky mountains of limestone which are characteristic of Palestine. The climbing community reveals its existence in many other ways and in many other spaces. If one looks at the Facebook account of the Wadi Climbing project, for example, it can be realized that Palestinian climbers have achieved the consolidation of a web of interrelationships and mutual links. On the Wadi Climbing Facebook wall one cannot only get information about climbing trips, boulder lessons, summer climbing camps for kids or new routes at the boulder gym. One can also interact with other climbers virtually and support or congratulate them for their success solving a boulder problem, for example. This proves the climbing community is alive and vibrant. It is mature enough to claim for and occupy its space.

Re-appropriating and re-defining space by developing climbing activities also allows for the redefinition of the self. Palestinians become locals again. The territory they have performatively built belongs to them and the other way around: they also end up belonging to the territory. A new landscape is created. The ability of climbers to build homeness and become locals in conflict areas proves that, as Michel de Certeau argued in L'invention du quotidien 1. Arts de faire (1990), "exhumer les formes subreptices que prend la créativité dispersée" (XL) is always possible. This means, exhuming the surreptitious ways taken by the disperse creativity ${ }^{7}$ cannot be avoided. People and civil society, by developing their quotidian routines and activities, can actually produce changes to improve the way of life of many others. The development of climbing activities in Palestine also implies a reflection on what frontier spaces consist of. From the Spanish climber B.'s point of view, climbing allows for a process of empowerment and she argued that "puede que los muros nos asusten menos y que sólo los veamos como paredes potencialmente escalables" (June

7 Translation from French to English is my own. 
2016), which means, maybe, walls would scare us less since we look at them only as potentially climbable surfaces. ${ }^{8}$ Climbing, then, becomes sport and something else. It is not only a physical activity but also a symbolic way of moving. As a symbol, climbing has also been used in artworks such as the film Omar (2013) directed by Hany Abu-Assad.

Finally, one can also conclude that, following Osama Cori, founder of Explore Jordan Adventure, a link between tourism, sustainability and peace is possible. Recreative activities such as outdoor rock climbing in Palestine become something beyond leisure. They imply alternative ways of experiencing space and building communities, two processes in which the starting point is pleasure.

\section{Bibliography}

Abraham Path: "About the Abraham Path". Online at: http://abrahampath.org/about-theabraham-path/ [Accessed June 28, 2016].

Agence France-Presse: "Palestinians in the rocky West Bank try climbing for sport", Aquila Style, April 20. 2015. Online at: http://www.aquila-style.com/focus-points/muslimlifestyle/palestiniansin-the-rocky-west-bank-try-climbing-for-sport/99700/ [Accessed June 28, 2016].

AMILHAT SZARY, Anne-Laure (2013a): "Towards experimental mountaineering?", Journal of Alpine Research, no 101(2), DOI: 10.4000/rga.2131.

- (2013b): "Mobile mountains?", Journal of Alpine Research, no 101(2).

A. GASS, Michael; GILLIS, H. L. "Lee" and RUSSEL, Keith C. (2012): Adventure Therapy: Theory, Research, and Practice, New York, Routledge.

BARRAT, Paul (2011): "Vertical worlds: technology, hybridity and the climbing body", Social and Cultural Geography, no 12(4), pp. 297-412, DOI: 10.1080/14649365.2011.574797.

BROWN, Jonathan: "Climbing community scales new heights in Palestine", Middle East Eye, June 22, 2015. Online at: http://www.middleeasteye.net/in-depth/features/climbing-palestine342818549 [Accessed June 28, 2016].

DEARDEN, Lizzie:. “Israel can now legally seize Palestinian homes in Jerusalem under 'absentees' property law", Independent, April 17, 2015. Online at: http://www.independent.co.uk/news/world/middle-east/israel-can-now-legally-seize-palestinianhomes-in-jerusalem-under-absentees-property-law-10184483.html [Accessed June 28, 2016].

DE CERTEAU, Michel (1990): L'invention du quotidien 1. Arts de faire, Paris, Gallimard.

CROMPTON, John L. and SELLAR, Christine (1981): “Do Outdoor Education Experiences Contribute to Positive Development in the Affective Domain?", The Journal of Environmental Education, no 12(4), pp. 21-29.

ERICKSON, Bruce (2005): "Style matters: Explorations of bodies, whiteness, and identity in rock climbing", Sociology of Sport Journal, no 22, pp. 373 - 396.

FANON, Frantz (2002): Les damnés de la terre, Paris, La Découverte/Poche.

FOUCAULT, Michel (2004). "Des espaces autres", Empan, no 54, pp. 12-19, DOI:10.3917/empa.054.0012

GARBIZU, Juanjo (2012): Monterapia, Bacelona, Editorial Diéresis.

GROSFOGUELI, Ramón (2013): “Racismo/sexismo epistémico, universidades occidentalizadas y los cuatro genocidios/epistemicidios del largo siglo XVI", Tabula Rasa, no 19, pp. 31-58.

8 Translation from Spanish to English is my own. 
HARAWAY, Donna J. (1991): Simians, cyborgs, and women: the reinvention of nature, New York, Routledge.

HATTEM, Ben: "Palestine's first planned city causes tensions", Middle East Eye, February 12, 2015. Online at: http://www.middleeasteye.net/news/palestines-first-planned-city-causes-tensions981710489 [Accessed June 28, 2016].

KHAN, Omar and HANNAH, Dorita (2008): "Performance/Architecture. An interview with Bernard Tschumi", Journal of Architectural Education, no 61(4), pp. 52-58.

LAMBERT, Léopold (2012): Weaponized Architecture: The Impossibility of Innocence, Barcelona, dpr-barcelona.

DE LÉSÉLEUC, Eric (2004): "Rock climbing and territory: symbolic processes in the appropriation of a public space", Revue de géographie alpine, no 92(4), pp. 95-103, DOI: 10.3406/rga.2004.4665.

LEWIS, Neil (2000): "The climbing body, nature and the experience of modernity", Body and Society, no 6(3-4), pp. 58-80.

LUTTENBERGER, Katharina; STELZER, Eva-María; FÖRST, Stefan; SCHOPPER, Matthias; KORNHUBER, Johannes and BOOK, Stephanie (2015): “Indoor rock climbing (bouldering) as a new treatment for depression: study design of a waitlist-controlled randomized group pilot study and the first results", BMC Psychiatry, no 15(201), DOI: 10.1186/s12888-015-0585-8.

M. BOGARDUS, Lisa (2012): "The Bolt Wars: A Social Worlds Perspective on Rock Climbing and Intragroup Conflict", Journal of Contemporary Etnography, no 41(3), pp. 283 - 308.

Nomadstravel: "Projects". Online at: http://www.nomadstravel.co.uk/projects/ [Accessed June 28, 2016].

PAPPE, Ilan (2007): The Ethnic Cleansing of Palestine, Oxford, Oneworld.

PHILCOX, Richard, trans. (2004): The wretched of the earth, New York, Grove Press

RAMOS TOLOSA, Jorge (2015): “¿No hay eco en el eco? El memoricidio de la Nakba y sus resistencias", Revista de Estudios Internacionales Mediterráneos, no 18, pp. 164 - 186.

RAWABI: "About Rawabi". Online at: http://www.rawabi.ps/about.php [Accessed June 28, 2016].

RIVEROLA, Víctor and SALVADOR, Jordi (2014): La montaña puede curar, Madrid, Ediciones Desnivel.

SMITH, Neil (2012): La Nueva Frontera Urbana. Ciudad Revanchista y Gentrificación, Madrid, Traficantes de Sueños.

DE SOUSA SANTOS, Boaventura (2010): Descolonizar el saber, reinventar el poder, Montevideo, Ediciones Trilce and Extensión Universitaria. Universidad de la República.

STICK, T. F. and SENIOR, N. (1984): "Adventure therapy: An innovative treatment for psychiatric patients", New Directions for Mental Health Services, no 21, pp. 103-108, DOI:10.1002/yd.23319842113.

TSCHUMI, Bernard (1996): Architecture and Disjunction, Cambridge and London, the MIT Press.

Wadi Climbing: "Outdoor Sites". Online at: http://www.wadiclimbing.com/outdoor-sites/ [Accessed July 27, 2016].

Walking "Abraham Path Initiative". Online at: http://www.walkingpalestine.org/pages/homepage/abraham-path-initiative.php [Accessed June 28, 2016].

WEIZMAN, Eyal (2012): Hollow land: Israel's architecture of occupation, London and New York, Verso.

WILSON, Nigel: "Palestine's rock-climbing community on the rise", Al Jazeera, October 3, 2015. Online at: http://www.aljazeera.com/news/2015/09/palestine-rock-climbing-community-rise150907150140747.html [Accessed June 28, 2016]. 